\title{
FORMULASI SEDIAAN LOTION EKSTRAK ETANOL BIJI KOPI ROBUSTA (Coffea cenephora)
}

\author{
Erda Wati ${ }^{1}$, Uci Dwi Cahya ${ }^{2}$, Yosi Darmirani ${ }^{3}$ \\ Institut Kesehatan Medistra Lubuk Pakam, Deli Serdang, Sumatera Utara. \\ e-mail : erdaw1527@gmail.com \\ DOI $10.35451 / \mathrm{jfm} . v 3 \mathrm{i} 2.570$
}

\begin{abstract}
Bean robusta coffee contains polyphenol compounds which are useful as antioxidants. Antioxidants can deactivates the progression of oxidation reactions formation of free radicals. Robusta coffee bean is an ingredient that can be formulated into lotion preparations. Cosmetic lotion aims to rbrighten the skin and soften the skin. This research aims to make lotion preparations from robusta coffee bean extract. This research uses pure experiment. Robusta coffee beans are extracted by maceration process. The lotion formulation is made with variations of robusta coffee bean powder with a concentration of $2 \%, 3 \%$, and $4 \%$. The characteristic test includes organoleptic test, homogeneity test, Ph test, and irritation test. The rule was to determine the lotion. The results of the lotion test had a homogeneous concentration of $2 \%, 3 \%$ and $4 \%$, light brown to blackish brown, with a distinctive smell of coffee. The ph lotion test had a $\mathrm{PH}$ of 5 in all formulations on the blank had a $\mathrm{PH}$ of 6 . The irritation test on the lotion preparation showed no erythema and edema in 5 volunteers. From all the tests carried out, the lotion formulation has good characteristics.
\end{abstract}

Keywords: Robusta coffee bean extract (Coffea canephora), Iotion.

\section{Pendahuluan}

Radikal bebas bersifat reaktif dan jika tidak dinetralkan akan merusak makromolekul penyusun sel yaitu protein, karbohidrat, lemak, dan asam nukleat yang dapat menyebabkan penyakit degeneratif. (Langseth, 1995). Pada sel kulit radikal bebas akan merusak senyawa lemak pada membran sel sehingga kulit kehilangan ketegangannya dan muncul keriput pada kulit (Silalahi, 2006). Sinar UV merupakan sumber radikal bebas dari luar tubuh, sinar UV yang berlebihan dapat menimbulkan beberapa masalah pada kulit, mulai dari pigmentasi, penuaan dini, bahkan dalam jangka waktu lama menyebabkan resiko kanker.

Antioksidan merupakan zat yang dibutuhkan tubuh untuk menetralkan radikal bebas dan mencegah kerusakan akibat radikal bebas pada sel normal, protein, dan lemak. Antioksidan yang diproduksi didalam tubuh tidak cukup untuk melawan radikal bebas, maka dari itu diperlukan asupan antioksidan dari luar tubuh.

Kopi Robusta (Coffea robusta) merupakan tanaman budidaya berbentuk pohon yang termasuk dalam famili Rubiaceae dan genus Coffea. Daunnya bulat telur dengan ujung agak meruncing. Daun tumbuh berlawanan dengan batang, cabang dan ranting. Permukaan daun bagian atas mengkilat, 
tepi rata, pangkal tumpul, panjang 5-15 $\mathrm{cm}$, lebar 4,0-6,5 cm, menyirip, panjang $0,5-1,0 \mathrm{~cm}$, dan hijau.(Najiyati dan Danarti, 2012).

Dalam penelitian sebelumnya, Bettina dan Lothar (2006) menyatakan bahwa ekstrak biji kopi robusta mengandung polifenol tinggi yang berperan penting sebagai antioksidan. Aktivitas antioksidan dapat menonaktifkan perkembangan reaksi oksidasi dengan membentuk radikal bebas. Berdasarkan uraian diatas, maka dilakukan penelitian formulasi dan uji stabilitas fisik antioksidan sediaan lotion ekstrak biji kopi robusta.

\section{METODE}

Penelitian ini merupakan jenis penelitian eksperimen murni (true experiment), metode yang digunakan untuk mencari pengaruh. Penelitian ini menggunakan kelas control sebagai pembanding, metode ini digunakan atas dasar pertimbangan bahwa sifat penelitian eksperimental yaitu mencoba sesuatu untuk mengetahui atau akibat dari suatu perlakuan.

a. Alat dan Bahan

Alat-alat yang digunakan pada penelitian ini adalah neraca analitik, mkiskroskop, $\mathrm{pH}$ meter, blender, stamper, mortir, objek glass, pot plastik, spatula, batang pengaduk, glass ukur, tabung reaksi, beaker glass, corong pemisah, kertas saring, rotary evaporator. Bahan-bahan yang digunakan dalam penelitian ini adalah biji kopi robusta, asam stearat, TEA (trietanolamin), propilen glikol, setil alkohol, metil paraben, propilen paraben, aquadest, etanol $96 \%$.

b. Formulasi Sediaan Lotion

R/ Asam Strearat 2\%

Trietanoolamin $1 \%$

Propilenglikol 3\%

Ekstrak kopi robusta

Metil Paraben 0,2\%

Propilen Paraben 0,02\%

\section{Aquadest $100 \mathrm{~mL}$}

Konsentrasi ekstrak biji kopi robusta yang digunakan dalam penelitian ini yaitu : formulasi I sebagai blanko, formulasi II $(2 \%)$, formulasi III $(3 \%)$, formulasi IV (4\%).

\section{HASIL}

a. Skrining Fitokimia

Penentuan golongan senyawa kimia ekstrak biji kopi robusta dilakukan untuk mendapatkan informasi golongan senyawa metabolik sekunder yang terdapat didalamnya. Adapun pemeriksaan yang dilakukan terhadap ekstrak adalah pemeriksaan golongan alkaloid, flavonoid, saponin dan tanin. Hasil skrining fitokimia ekstrak biji kopi robusta dapat dilihat pada tabel 1 .

Tabel 1 Skrining Fitokimia

\begin{tabular}{ccc}
\hline No & $\begin{array}{c}\text { Skrining } \\
\text { Fitokima }\end{array}$ & $\begin{array}{c}\text { Ekstrak } \\
\text { Biji kopi } \\
\text { robusta } \\
\text { (Coffea } \\
\text { Canephora) }\end{array}$ \\
\hline $\mathbf{1}$ & Alkaloid & + \\
\hline $\mathbf{2}$ & Flavonoid & + \\
\hline $\mathbf{3}$ & Saponin & + \\
\hline $\mathbf{4}$ & Tanin & + \\
\hline
\end{tabular}

Pada tabel 1 tersebut menunjukkan bahwa ekstrak biji kopi robust memiliki kandungan senyawa kimia atau metabolik sekunder yaitu mengandung alkaloid, flavonoid, saponin dan Tanin.

b. Foromulasi Sediaan Lotion Kopi Robusta

Sediaan lotion dengan penambahan ekstrak biji kopi robusta masing masing 2\%, 3\%, 4\% berwana Kecoklatan. Lotion blangko berwarna putih dapat dilihat pada tabel 2.

Tabel 2 Pemeriksaan $\mathrm{pH}$ sediaan.

\section{No FORMULASI JUMLAH PH}

\begin{tabular}{lll}
\hline 1 & F1 (2\%) & 5 \\
\hline 2 & F2 (3\%) & 5 \\
\hline 3 & F3 (4\%) & 5 \\
\hline
\end{tabular}




\begin{tabular}{|c|c|c|}
\hline 4 & $\begin{array}{l}\text { BLANKO } \\
\text { (tanpa } \\
\text { ekstrak) }\end{array}$ & 6 \\
\hline
\end{tabular}

Hasil uji iritasi terhadap kulit sukarelawan yang dioleskan pada kulit tipis seperti pada belakang telingan. Hasil dapat dilihat pada tabel 3.

Tabel 3 Uji Iritasi

\begin{tabular}{llllllll}
\hline No & Reaksi & \multicolumn{6}{c}{ Sukarelawan } \\
\cline { 3 - 7 } & Iritasi & 1 & 2 & 3 & 4 & 5 & 6 \\
\hline $\mathbf{1}$ & Eritema & 0 & 0 & 0 & 0 & 0 & 0 \\
\hline $\mathbf{2}$ & Edema & 0 & 0 & 0 & 0 & 0 & 0 \\
\hline
\end{tabular}

\section{KESIMPULAN}

Ekstrak biji kopi robusta (Coffea Canephora) dapat diformulasikan dalam bentuk sediaan lotion yang homogen dengan konsentrasi $2 \%, 3 \%, 4 \%$, dengan $\mathrm{Ph}$ 5-6 tidak menimbulkan iritasi kulit dan stabil dalam penyimpanan selama 3 hari pada suhu kamar.

Sediaan lotion ekstrak biji kopi robusta (Coffea Canephora) dengan formulasi paling tepat yaitu konsentrasi $2 \%$ sediaan lotion homogen dan tidak menimbulkan iritasi, dan memiliki ph 5 .

Hasil organoleptis sediaan lotion untuk konsentrasi $2 \%$ terbentuk homogen, dan berwarna coklat muda dengan bau khas kopi dengan ph 5, lotion konsentrasi $3 \%$ terbentuk homogen, dengan warna coklat gelap dengan bau khas kopi yang menyengat dan memiliki ph 5 , dan lotion konsentrasi $4 \%$ terbentuk homogen dengan warna coklat kehitaman dengan bau khas kopi sangat menyengat dan memiliki Ph 5.

\section{DAFTAR PUSTAKA}

Aliva, N. F. Melrota, S. dan Karin, Z, (2013). Stabilitas Fisik Sediaan Sediaan Lotion O/W dan W/O Ekstrak Buah Mahkota Dewa Sebagai Tabir Surya Dan Uji Iritasi Primer Pada Kelinci. Hal. 141-150.

Ansel, H, C., (1989). Pengantar Bentuk Sediaan Farmasi, Edisi
Keempat. Jakarta: Universitas Indonesia Press.

Ansel, H. C., (2005). Pengantar Bentuk Sediaan Farmasi. Edisi Keempat. Jakarta: Universitas Indonesia Press. Hal. 162-163, 357-389.

Clarke, R. J. dan R. Macrae. (1989). Coffe Chemistry. I dan II. Elsevier Aplated Science. London and New York.

Cronquist, A., (1981). An Intedgrated System of Classifikation of Flowering Plants, New York, Colombia. University Press. Hal. 477.

Ditjen POM. (1985). Formulasi Kosmetika Indonesia. Edisi Kelima. Jakarta: Depertemen Kesehatan RI. Hal. 22, 83, 9697, 356.

Ditjen POM. (1995). Farmakope Indonesia. Edisi Kelima. Depertemn Kesehatan RI, Jakarta.

Ditjen POM. (2000). Parameter Standar Umum Estrak Tumbuhan Obat. Departemen Kesehatan RI. Jakarta: Hal. 3-5, 13-17, 30-31.

Erungan, A. C., S. (2009). Aplikasi Keraginan Dalam Pembuatan Skin Lotion. J. Teknologi Hasil Perikanan Indonesia. Hal. 128.

Fadhilah, R., (2018). Formulasi Krim Lulur Dari Ekstrak Rumput Laut dan Keragenan, Dapertemen Teknologi Hasil Perairan, Fakultas Perikanan dan Ilmu Kelautan, Institut Pertanian Bogor.

Farah, A. (2012). Coffee Constituens in Coffee. Emerging Health Effects and Reven Reventron. First Edition United Kingdom: Black Well Publishing Ltd.

Hanani. (2015). Analisis Fitokimia. Jakarta: EGC.

Haryanto. (2014). Asesmen Pendidikan. Bandun. PT Remaja Rosdakarya.

Hecimovic, L., Cvitanovic, A, B., D and Komes,D. (2011).Comperative Study. F Polyphenols and Caffeine In Diffcrent Coffe Varieties Effected By The Degree Of Roasting. Food Chemistry. 
Hidayato, H. S, dan Karim, Z. (2013). Stabilitas Fisik Sediaan Lotion O/W dan W/O Ekstrak Buah Mahkota Dewa Sebagai Tabir Surya dan Uji Iritasi Primer Pada Kelinci. Hal. 109-117.

Karim, Dkk. (201 3).Stabilitas Sediaan Kosmetika Jurnal FMIPA IImiah. Hal. 86.

Kumalaningsih, S. (2006). Antioksidan Alami Penangkal Radikal Bebas. Surabaya: Trubus Agrisarana.

Lachman, L., dan Libermen, H. A., (1994). Teori dan Praktek Farmasi Industri, Edisi Kedua, UI Press, Jakarta.

Langseth, L., (1995). Antioxidant, and Desease Prevention, International Life Scrience Institute Press, Belgium.

Maharani, Ayu. (2015). Penyakit Kulit, Perawatan, Pencegahan, dan Pengobatan. Yogyakarta: Pustaka Baru Press.

Mutua, J. (2000). Post Harvest Handling and Processing Of Coffe in African Countries.

Novi Pramuditha. (2016). Uji Stabilitas Fisik Lulur Krim Dari Ampas Kelapa (Cocos nuciferal L) Dengan Menggunakan Emulgator Anionik Dan Nonionik. Skripsi Farmasi. Fakultas Kedokteran Dan Ilmu Kesehatan. Universitas Negri Allaudin: Makasar.

Palacios, H. A., H. C. Menezes, B.T. Iamanaka, F. Canepa, A. A. Teixeira, N. Calvalheas, D. Santi, P. T. Z. Leme, K. Yotsuyanagi and M. H. Taniwaki. (2007). Efect of Temperatur and Relative Humiduty during Transportation on Green Coffe Bean Moisture Content and Ochratoxin A Production. Jurnal of Food Protection. 7(1): 164171.

Pangabean, E. (2011). Buku Pintar Kopi. PT. Agro Media Pustaka. Jakarta. Prakash, A., Antioxidant Activity., Medallion Laboratories: AnalithycalProgres, (2001). Vol 19 No: 1-4.

Purba, R. Y. (2016). Skrining Fitokimia dan Penggunaan Buah Belimbing Manis (Averrhone
Caranbola. L). Sebagai

Pelembab Dalam Krim Cair Tangan Dan Badan. Medan. Universitas Tjut Nyak Dhien.

Ridwansyah. (2003). Pengolahan Kopi, Jurusan Teknologi Pertanian, Fakultas Pertanian. Universitas Sumatera Utara.

Rothfos, B. (1986). Coffe Production. Hambang: Gordian- Max- Rieck$\mathrm{GmbH}$.

Rowe, R. C et al. (2003). Handbook of Pharmaceutical Exeipient, $4^{\text {th }}$ ed. Pharmaceutical Press.

Silalahi , J., (2006). Makanan Fungsional. Kaisius, Yogyakarta. Hal: 40-48.

Tranggono, RI. dan Latifa F. (2007). Buku Pangan Ilmu Pengetahuan Kosmetik. Penerbit Pustaka Utama. Jakarta, Indonesia.

Wasitaatmadja, S. M. (1997). Penuntun Iilmu Kosmetik Medik, Universitas Indonesia Press. Jakarta.

Wasitaatmadja, S. M.(2011). IImu Penyakit Kulit dan Kelamin. Edisi 6. Jakarta: Balai Penerbit FKUI.

Yoigh, R., (1995). Buku Pelajaran Teknologi Farmasi. Yogyakarta: UGM Press. 